\title{
AZ OTTHONTEREMTÉS JÖVŐJÉNEK KATALÓGUSA
}

\section{THE CATALOG FOR OUR FUTURE HOME}

\author{
Molnár Eszter, ${ }^{1}$ Borsos Ágnes ${ }^{2}$ \\ Pécsi Tudományegyetem Müszaki és Informatikai Kar, Pécs, Magyarország \\ ${ }^{1}$ meszter.arch@gmail.com \\ 2 agnesborsos@mik.pte.hu
}

\begin{abstract}
Today's continuously growing society has a strong influence on efficiency within the construction industry. The need to build new homes in a shorter period of time increases. Finding the solution to this problem is a key element in today's world. In connection with this there was a defining initiation in the 1900s with the development of „type design”, which even today has a significant role in architecture. These „type design” buildings used parts which were prefabricated, making certain phases of construction quicker. At the end of the XX. century the appearance of these plans seemed to be insufficient for the expected result. In the XXI. century there is an attempt to create another plan sample catalogue which can reflect building to productivity and try to minimalize the time for home development.
\end{abstract}

Keywords: home, future, catalog, type design, prefabrication.

\section{Összefoglalás}

A folyamatosan növekvő társadalom a mindennapok rohanásában az építőipar hatékonyságát jelentős mértékben befolyásolja. Egyre nagyobb az igény újabb és újabb otthonok létrehozása iránt minél rövidebb idő alatt. Ennek megoldása napjaink egyik kiemelkedő feladatává vált. Ezzel kapcsolatban már az 1900-as években megjelent egy fontos kezdeményezés a típustervek létrehozásával, melyek közül megannyi jelenleg is meghatározó szerepet tölt be. Ezek az épületek már magukban hordozták az előregyártás különféle elemeit, mellyel a különféle munkafázisokra fordított időtartamot sikerült csökkenteni. A XX. század végén azonban ezeknek a terveknek a megjelenése csekély volt, és nem hozták meg a kívánt eredményt. A XXI. században újabb kísérletet tesznek egy mintaterv-katalógus létrehozására, mely reflektálhat az építőipar termelékenységére, és egy otthon létrehozásához szükséges időt csökkentheti.

Kulcsszavak: otthon, típusterv, katalógus, elöre gyártás, jövő.

\section{Bevezetés}

Az otthonteremtés napjaink egyik kiemelkedő megoldásra váró feladata. Jelenkori törekvések is ezt igazolják, hiszen egyre több otthonteremtési támogatást hoznak létre annak érdekében, hogy mindenki igényét kiszolgálják. A támogatások megjelenése azonban nem minden szempontból jelent megoldást. Az építőipar megterhelése növekvő tendenciát mutat, melynek köszönhetően egyre kevésbé lesz képes ellátni időben a ráháruló feladatokat. Az egyik legnagyobb jelenlevő probléma az építőanyagok és a jó munkaerő hiánya, melyekből folyamatos késlekedések és többletköltségek alakulhatnak ki egy kivitelezés során. Ezek a gondok már a XX. században jelen voltak, és erre minduntalan igyekeztek megoldást találni. Ennek a problémának napjainkig nem sikerült a végére járni, azonban megjelent egy komolyabb próbálkozás egy új mintaterv-katalógus létrehozására. A mintaterv-katalógus magában foglal 
számos korszerü és régi korokat megidéző típusterveket. Ezek olyan ötletek és tervek, melyek ismételhetők, sokszorosíthatók, többször is felhasználhatók különféle területeken és telepítési helyzetekben. Ezek az épületek azonban az alapkoncepciót megtartva, az adott helyszínre adaptálva minden egyes alkalommal egyedi értéket fognak képviselni. A mintatervek a kiviteli szintű tervek mellett egy BIM-modellt is tartalmaznak, melyek helyszíni megtekintésre is alkalmazhatók egy-egy ellenőrzés vagy fennakadás esetén, illetve már a tervezés során felmerülő akadályok kiküszöbölésére is alkalmasak.

\section{A XX. század típustervei}

Európa lakosságának száma az 1950-es évek óta napjainkig közel 200 millió fővel növekedett [1]. Az építőipar ezzel a folyamatosan gyarapodó népességgel és az újonnan megjelenő igényekkel próbálja tartani a lépést. A XX. században végbemenő ipari forradalomnak köszönhetően számos technológia alakult ki, melynek köszönhetően az építéstechnológia folyamatosan fejlődött. A megjelenő eszközök nemcsak a technológiákat alakí-

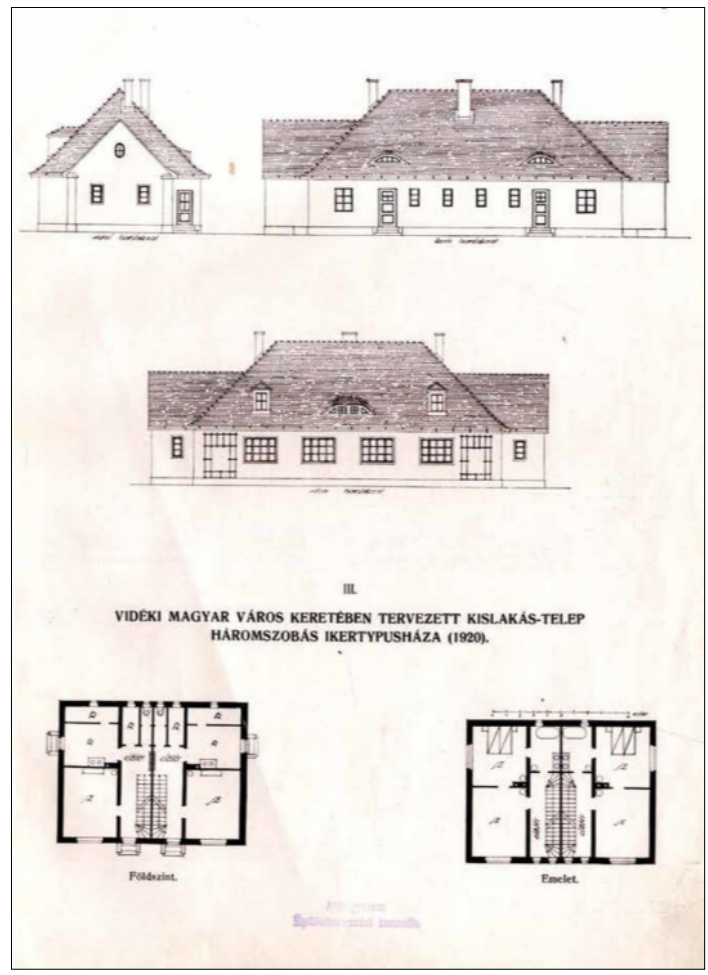

1. ábra. Vidéki magyar város keretében tervezett kislakás-telep háromszobás ikertípusháza, 1920. [2] - 1/18-as kép tották át, hanem a mindennapi élethez szükséges funkciókban is meghatározó szerepet töltöttek be (1. ábra). A városok fejlesztése a népesség gyarapodásával növekvő tendenciát mutatott, míg a falvak folyamatos elszegényedést és elhagyatottságot mutattak. Közel 507 olyan zsáktelepülés alakult ki, melyek csupán egy útvonallal kapcsolódnak a fő tengelyekhez. Ezeknek a településeknek a gazdasági helyzete a XX. században meginduló urbanizáció hatására redukálódott, és1970-2011 között a vizsgált települések népessége 71\%-kal csökkent [2]. Annak érdekében, hogy a települések ne váljanak semmivé, már az 1900-as évek első ütemében olyan törekvések jelentek meg, melyek az otthonok hiányos helyzetének megoldására és az eltűnések megelőzésére adhatnak választ. Az első lépések között volt Darányi Ignác segélyezési indítványozása, melyet a minisztérium lépései követtek. Ezeknek a lényege egy mintaház-akció meghirdetése volt, melyek közül számos épület tekinthető a század első mintaházpéldájának.

Ezt követte Lechner Ödön újabb pályázata, mellyel egy időben jelentek meg hitelekkel kapcsolatos támogatási programok. 1927-ben a Falusi Kislakásépítő Szövetkezetek által került meghirdetésre az első ilyen program, melynek köszönhetően közel 43000 embernek adtak kölcsönt kizárólag lakásépítés céljából. 1940-ben hozták létre az Országos Nép- és Családvédelmi Alapot. A programnak köszönhetően, több, mint 12000 típuslakást építettek fel a rászoruló nagycsaládok részére. Ezeket a terveket a mintaterveknek megfelelően kivitelezték, amit a különböző tájegységek épületei inspiráltak. 1948-ban létrehoztak egy mintaterveket összefoglaló kötetet, mely az egy évvel korábban meghirdetett pályázati anyagokat tartalmazta. Ebben a pályázati anyagban három csoportot különböztettek meg: a gazdálkodó-lakóház, munkáscsalád-lakóház és a szellemi foglalkozásúak számára tervezett házak csoportját. A kötetnek megjelenésével egy időben megjelent egy rendelet, amely megfogalmazta, hogy a tervekhez tartozó engedélyek díjmentesek legyenek. A II. világháborút követő időszakban a központilag épített lakóépületek és a falusi otthonok kerültek előtérbe. A lakóépületek a növekvő munkaerő elszállásolására voltak alkalmasak a telephelyekhez közel, ezzel is növelve a munkásosztály kiszolgálását. A népességnövekedés és a városokban megjelenő kedvező kínálatok a városok felé meginduló tömeget eredményezték. 1956 után szüntették meg az államosítást, mely a magánlakás-építések újraindítását tette lehetővé. 
Több mint 700000 elavult és elhagyatott lakás megszüntetését tűzték ki célul. Az 1966. évi törvényben fogalmazták meg: „A lakásviszonyok javítására 300 ezer lakás építését kell biztosítani, állami lakás ebből 100 ezer legyen. Hiteltámogatással, megfelelő anyagellátással és építőipari kapacitással elő kell segíteni 200 ezer lakás magánerőből történő magánépítését”. Továbbá azt is megfogalmazták, hogy „10 milliárd forint hosszú lejáratú hitellel, típustervekkel segítsék a lakosságot”. Az 1960-as évek végén meghirdettek egy országos szintű pályázatot, melynek hatására megépítették Bitó János tervét, amely később a mintaházak elemeként szolgált. A terveknél figyelembe kellett venni az akkoriban jelen levő építőanyagokat és technológiákat is a kivitelezhetőség érdekében. Az 1970-es évek végén megjelent egy hasonló tervpályázat, mely 135 tervet tartalmazott, és 2 katalógus is készült belőle: Magánlakás-építés ajánlott tervei és a családi házak. Ebben az időszakban ezek a típustervek nagy hírnévre tettek szert (2. ábra). 10 év alatt több mint 100 ezer tervet értékesítettek. A típustervek folyamatos fejlesztése mellett megjelent az igény a melléképületek létrehozá-

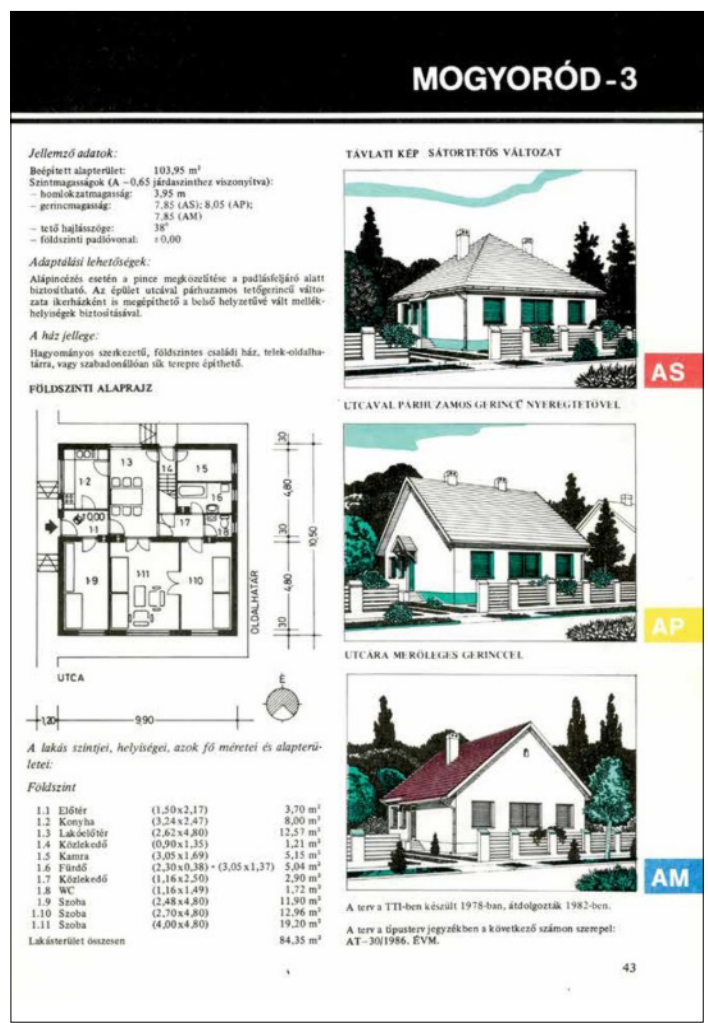

2. ábra. A magánerős lakásépítés ajánlott tervei, 1988, [3] - 10/18-as kép sára és a tetőterek beépítésére. 1990-től a cégek által ajánlott típustervek kezdték uralni a piacot. Ennek a következménye egy nehezen átlátható kínálat lett az építtetők számára. Ezzel az indíttatással egy időben megjelent a magánérdek felértékelődése, és a magánépítészek vették át az irányítást a mintaházak felett [4].

\section{A XXI. század típustervei}

A XXI. századra kialakult magánérdekek előtérbe helyezésének végeredménye a mintaházak számának csekély számban való megjelenése lett. A 2015-2016-os években létrehoztak egy kormányrendeletet a Családok otthonteremtési kedvezménye néven, amely anyagi segítséget nyújthat azoknak, akik saját ingatlant szeretnének. A Lechner Tudásközpont által létrehozott statisztikai adatok megmutatják, hogy a városok lélektani száma milyen mértékben növekedett 2001-től 2011-ig [5]. Ezt a kialakuló urbanizálást a városok által nyújtott kedvező életkörülmények váltották ki. Nagyobb a választék a munkahelyek, a beiskoláztatás és a lakókörülmények között is. Ez a megoldás egyszerübbnek kínálkozik, mint a falvakból való bejárás a városközpontokba. A Lechner Tudásközpont létrehozott egy Zsáktelepüléseink kétarcúsága elnevezésű interaktív térképet, mely megmutatja hogyan változik napról napra az alacsony lélekszámú települések aránya [6]. Egy további térkép, melyet szintén a Lechner Tudásközpont hozott létre, pedig megmutatja, hogy különböző életszakaszokban miként változtak a különböző lakhatásra szolgáló épületek számai. A legnagyobb építési százalék jól láthatóan 1971-1980 közé integrálódott elszórtan az ország teljes területén. 2011-2014 között az a százalék már Budapestre és környékére korlátozódott, illetve csekély mértékben még egy-két nagyvárosra és környezetére [7]. Ezek az adatok is azt igazolják, hogy egyre többen keresnek lakhatást a nagyvárosokban akár szülőfalvakat, településeket is elhagyva ezzel. Ennek megelőzésére 2019-ben létrehozták a Falusi családok otthonteremtési kedvezményét, mely kimondottan a programban részt vevő falvakban ad anyagi támogatást a betelepülőknek. A falvakban egy családi ház egy nagyvárosi kislakáshoz képest jutányos áron kínálkozhat az érdeklődők számára. Ezek az adatok azonban tájegységenként változnak, a nagyvárosokhoz közeledve növekedhetnek. Számolva azzal, hogy a kedvező családtámogatási programoknak köszönhetően a lélektani arány gyarapodik a községekben, a Lechner Tudásközpont 2019 
áprilisában kiadott egy országos ötletpályázatot egy új mintaterv-katalógus létrehozására, melynek kiadását 2020-ra ütemezik. A 273 beérkezett tervből 93 mintaház került megvásárlásra. Ennél a pályázatnál is megjelenik a hármas csoportosítás, mint az 1948-ban létrehozott ötletpályázatban. Ezek a kategóriákat a mindennapok igényeinek megfelelően hirdették meg: a Kádár-kockák újragondolása, a kalákában megépítendő családi házak és az okosotthonok formájában.

Ezeknek az objektumoknak a megtervezésénél figyelembe kellett venni a mobilitást a különböző beépítési módokhoz és terepviszonyokhoz való alkalmazhatóság okán. A cél, hogy az ingatlanok létrehozása során a tervezéstől kezdődően a kivitelezésig minden gördülékeny legyen, és az időtartam ne növekedjen jelentős mértékben a kialakuló hiányok és problémák miatt. Ebből kifolyólag ezek a tervek már rendelkeznek a szükséges számú engedélyekkel, illetve előregyártott elemekből készülnek. Az üzemekben előkészített szerkezetek és az adott elemekhez tartozó cégek által biztosított munkaerő hatására minimalizálható a késedelmi fázisok aránya, és ezzel együtt a halmozódó többletköltségek aránya is. A megvásárolt épületek között jobbnál jobb és különféle frappáns megoldások találhatók, azonban mindegyik terv tükrözi a falvakban megjelenő formavilágokat valamilyen jelképként. Ezzel az új mintaterv-katalógussal egy újabb korszak kezdődhet el a községek fejlesztésének életében. Ezekkel a létesítményekkel a kívülálló, elnéptelenedő falvakban megjelenhet a modernizáció, a technológiai fejlődések maradandó nyoma, és ezáltal vonzóbbá válhatnak a társadalmi rétegek számára, mely népességnövekedést eredményezhet az elnéptelenedő településeken. A 2020-ban megjelenő mintaterv-katalógus elődjeinek tapasztalataiból merítettek ihletet egy korszerü összefoglalás megalkotására, mely a tervek szerint minimum

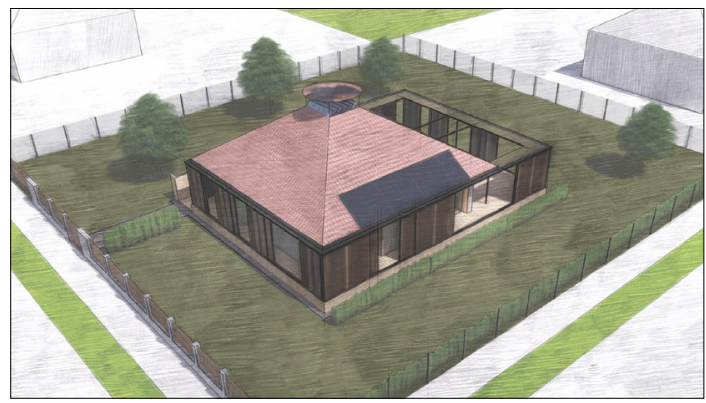

3. ábra. Lechner-mintaterv-katalógus: Kockaház-átalakitás, Hegedüs Csilla terve. [8]
50 évig kiszolgálhatja az építtetőket és tervezőket is egyaránt (3. ábra). Ezek a mintaterv-katalógusok ugyanis nem csak azok számára kínálnak megoldást, akik saját otthont szeretnének teremteni, hanem egyfajta útmutatást is adhatnak a tervezőknek, akik inspirációt szerezhetnek egy-egy stílusirányzatból, és ezáltal fejleszthetik és tágíthatják saját látásmódjukat. A mintatervek lényege a szerkezetek teljes mértékű előregyártása és helyszíni összeszerelése. Ezek a megoldások az ábrán is látható mértékben befolyásolják az átlagos otthonok létrehozásához képest az építési ciklusra. A bevezetésben már szó volt a BIM-modell létrehozásáról, mely újdonságként szerepel a mintatervek életében, hiszen a XX. században ezzel még nem tudtak szolgálni. Ezeket a terveket a helyszínen tabletek vagy különböző hordozható eszközök segítségével megnyitva, egyszerűen áttekinthetővé válik az épület szerkezetileg és esztétikailag is. Ezek a tervek egy általános otthon létrehozásával szemben nem tartalmaznak rejtett költségeket, hiszen előre meghatározott ütemterv készül hozzájuk. Ezzel reagálhatnak arra a problémára, mely a különféle építkezések során létrejövő többletköltségekkel járhatnak, illetve a kivitelezést is meggyorsíthatják az előregyártott elemek és a kivitelezést megelőző gördülékeny tervadaptációk is egyaránt. A diagramon jól látható a különbség, mely mindegyik esetben a legrosszabb és legköltségesebb helyzeteket feltételezi (4. ábra).

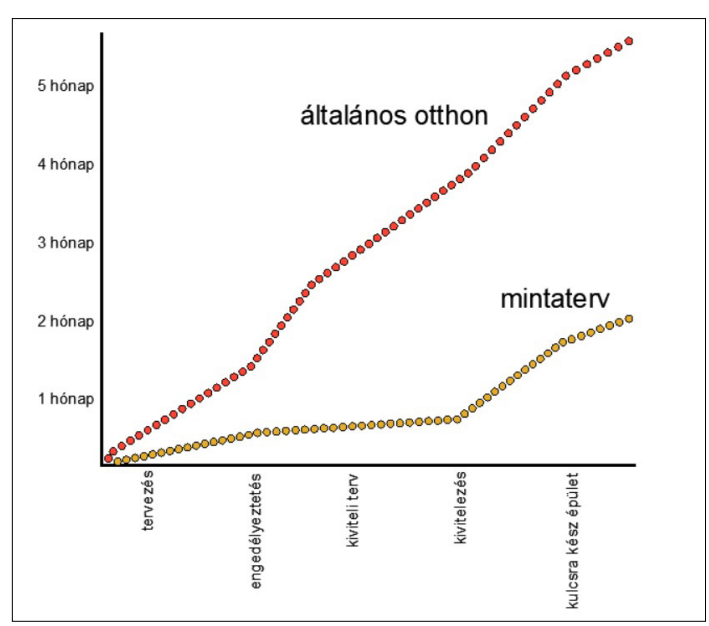

4. ábra. A mintatervek és általános otthonok létrehozásának ciklusai (saját ábra) 


\section{Okosotthon}

Ebben a fejezetben a típustervpályázatra készített tervemet, annak koncepcióját és konklúzióját fogom bemutatni. A terv létrehozásában a [9-19] voltak az inspirációim. Az általam választott okosotthon-kategória kiemelkedő részét képezi az elöregedő települések fejlődésében, hiszen az ott megépülő létesítmények korszerüsítése napjainkban elengedhetetlenné válik. Az alaprajzi elrendezésnél figyelembe vettem a különböző helyiségek egymáshoz való viszonyait és kapcsolatait a különböző társadalmi változások figyelembe vételével. Napjainkban előtérbe kerülnek az amerikai típusú konyhák, így tervemben is hasonlóképpen került kialakításra a konyha. Az egybenyitott terek egyre inkább praktikussá és esztétikailag elhanyagolhatatlanná válnak. A földszinti és emeleti elrendezésben is egyaránt érvényesül az egybenyitott terek növelése optikai hatások eszközének segítségével (5. ábra). Az épületen elhelyezett nagyméretű nyílászárók megfelelő elhelyezése csak erősíti az optikailag megnövelt térérzetet (6. ábra). A funkciók úgy kerültek kialakításra, hogy a különböző telekhelyzeteknél megjelenő tájolásoknál alkalmazhatók legyenek. A helyiségek kialakításánál a tájoláson kívül az otthonteremtési programokban meghatározott négyzetméterarányok is meghatározó szerepet képviseltek. A terv egy négyfős család számára készült, így három hálószoba helyezkedik el az emeleten. Az otthonok megtervezésénél egyik

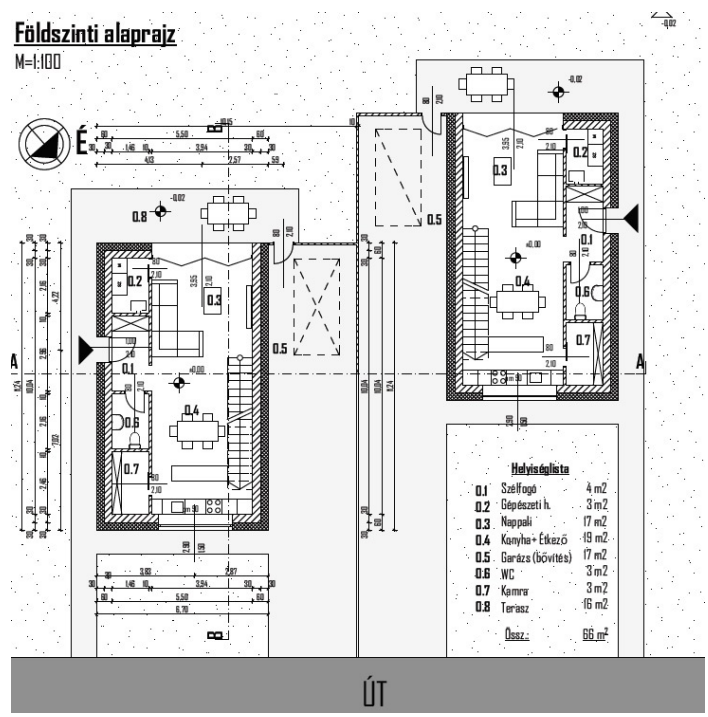

5. ábra. Lechner Mintaterv Katalógus-tervpályázatára készült ikerház beépítéses családi ház (saját terv)

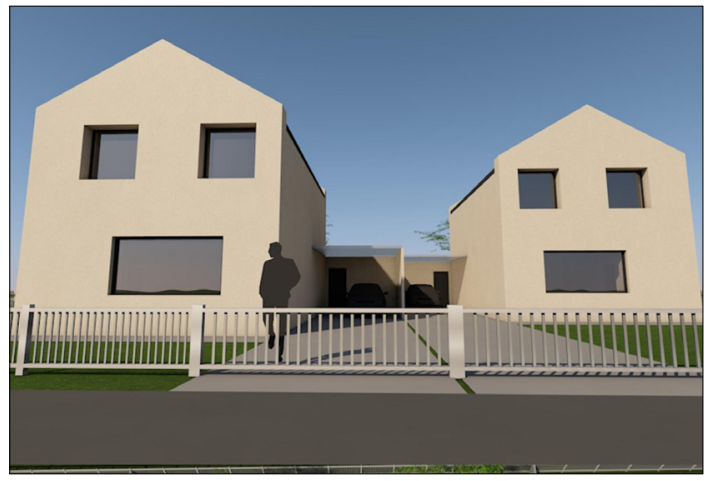

6. ábra. Lechner Mintaterv Katalógus-tervpályázatára készült saját tervezésü okosotthon látványterve (saját terv)

kritérium a későbbi bővíthetőség volt, melyet egy adott helyiséggel vagy külső kertkapcsolattal kellett elérni.

Az okosotthon kategóriában a különböző természeti elemek hasznosítását tǔztem ki célul, ezért a tetőburkolaton megjelennek napelemmel rendelkező cserepek, melyek ellátják az épület energiakészletét. Elektromos fütés, illetve légkondicionálás került kialakításra és olyan szellőztetőberendezések, melyek nem igényelnek számottevő energiafelhasználást. Az épület szerkezete előregyártott elemekből lenne kivitelezhető, mely gördülékennyé tenné az építkezést.

\section{Következtetések}

A mintaterv-katalógusok kihívása továbbra is a fennmaradásuk és a mindennapi életbe való integrálódásuk. A Lechner által létrehozott katalógust fél évszázadra tervezik, mely egy kísérleti fázisként is felfogható, hogy hogyan tudnak érvényesülni ezek a tervek. A jelen katalógusban szereplő tervekben érvényesülnek a kortárs építészeti kifejezések és a régmúlt idők fortélyait felölelő elemek is, tökéletes egységet alkotva együtt. Az általam készített terv is ennek szellemében formálódott, és további fejlesztéseken megy keresztül, hogy minél élhetőbb és kivitelezhetőbb megoldás valósulhasson meg, mely megfelel a különböző társadalmi rétegekben megjelenő igényeknek, mint a napjainkban egyre fontosabbá váló környezettudatos életmód. A naponta újuló technológiákkal kísérletezve, a szerkezeti megoldások is nyomon követhetők lesznek annak érdekében, hogy az épület részletesen értelmezhető legyen. Ezt is segítheti a BIM- vagy más információs modellek felhasználása. Az előregyártásnak és a modern tervfeldolgozásnak köszönhetően 
komoly esélyekkel rendelkezik a típusterv annak érdekében, hogy a mindennapok építészetében figyelemre méltó szerepet tölthessenek be ezek az ismétlődő, de mégis egyedi érdekeket képviselő otthonok.

\section{Szakirodalmi hivatkozások}

[1] Központi Statisztikai Hivatal: A világ népessége kontinensek szerint, 1950-2100. Grafikon.

https://www.ksh.hu/interaktiv/grafikonok/ vilag_nepessege.html?fbclid=IwAR0Z93Apc6Nl1nlPcHnkS1hEyzp1SeFWZTBIP74m7lEMjE5HBAtMfMljevY

[2] Lechner Tudásközpont, Zsáktelepülések kétarcúsága, 2017. március 1.

http://lechnerkozpont.hu/cikk/zsaktelepuleseink-ketarcusaga

[3] Perényi T.: Mintaházak történeti áttekintése, Építész Forum, 2016.07.26.

https://epiteszforum.hu/mintahazak-torteneti-attekintese

[4] BME Lakóépületek tervezési tanszék: Családi házak katalógusa: Ajánlott tervek (letöltve 2019. október 09.)

[5] Lechner Tudásközpont: Lakónépesség változása 2001-2011.

http://portal.lechnerkozpont.hu/arcgisportal/apps/webappviewer/index.html?id=04ca645cf4794d3ab06eb15e0e59009a

[6] Lechner Tudásközpont: Zsáktelepülések statisztikai adatai

http://portal.lechnerkozpont.hu/arcgisportal/ apps/webappviewer/index.html?id=20352668bc1040439b9a09101ceb8aaf

[7] Lechner Tudásközpont: Lakásépítések leggyakoribb időszaka

http://webmap.lechnerkozpont.hu/webappbuilder/apps/foldgomb1701/
[8] Lechner Tudásközpont: Nemzeti mintaterv katalógus 2020.

http://nmtk.lechnerkozpont.hu/terv/nmtk070

[9] A modern építészet elemei-50 kortárs épület értelmezése. Terc, Budapest, 2014.

[10] Építésügyi ás városfejlesztési minisztérium: $L a-$ kás és lakókörnyezet 1983-85.

[11] Szövetkezeti láncházak, sorházak, Budapest, 1977.

[12] Építésügyi és Városfejlesztési Minisztérium: Tervpályázat'79 - magánerős lakóépületek panelos építéstechnológiával.

[13] Branczik M., Keller M.: Korszerü lakás, az óbudai kísérlet. 1960, Terc Kft, 2011

[14] Központi Statisztikai Hivatal: Települések a lét határán, Erősen fogyó népességü törpefalvak Magyarországon, 2014. április.

http://www.ksh.hu/docs/hun/xftp/idoszaki/regiok/fogyonep.pdf

[15] Perényi Tamás: Mintaházak történeti áttekintése, Budapest, 2015. november.

https://epiteszforum.hu/mintahazak-torteneti-attekintese

[16] Hornyik Sándor: A posztkommunista „magyar kocka”, 2014. április.

http://meonline.hu/archivum/a-posztkommunista-magyar-kocka/

[17] A magánlakásépítés ajánlott tervei: Családi házak. Építésügyi Tájékoztatási Központ, Budapest, 1986.

[18] Körner Zs., Nagy M.: Az európai és magyar telepszerü lakásépítés története 1945-től napjainkig. TERC Kft, Budapest, 2007.

[19] Kortárs magyar épitészet, Többlakásos házak. TERC Kft., Budapest, 2012. 